\title{
TEORI INTERNASIONALISME DALAM SISTEM HUKUM NASIONAL
}

\author{
Ninon Melatyugra \\ Alumnus Fakultas Hukum Universitas Kristen Satya Wacana dan Pengamat Hukum \\ Internasional \\ Korespondensi: ninon.melatyugra@gmail.com
}

\begin{abstract}
Abstrak
Konstitusi suatu negara memegang peran penting dalam menjelaskan posisi hukum internasional dalam sistem hukum nasional. The South African Constitution adalah salah satu contoh konstitusi yang menjabarkan secara eksplisit mengenai kedudukan hukum internasional sehingga mempreskripsi pengadilan untuk menggunakan hukum internasional secara langsung dalam wilayah domestik. Masalah muncul bagi negara yang tidak memiliki ketentuan eksplisit dalam konstitusi, seperti Indonesia, namun praktiknya terdapat penggunaan hukum internasional oleh agen negaranya. Artikel ini menawarkan teori internasionalisme untuk memberi dasar legitimasi bagi negara yang ingin patuh terhadap hukum internasional di saat konstitusi tidak memiliki ketentuan eksplisit yang mengaturnya. Teori ini dibangun dengan fondasi 2 teori yakni teori transnational legal process yang menitikberatkan pada bagaimana negara memperlakukan hukum internasional, dan teori international constitution yang berfokus pada bagaimana perlakuan hukum internasional tersebut bersifat konstitusional.
\end{abstract}

Kata-kata Kunci: Internasionalisme; Konstitusi; Hukum Internasional.

\begin{abstract}
A constitution of a nation holds an important role to define international law before municipal law. The South African Constitution is an example of constitutions that explain explicitly the position of international law and prescribe its courts to observe international law in domestic zone. A crucial problem has risen in States which have no explicit provisions in their constitutions, like Indonesia, but the State agent acts of using international law are often found. This article offers internationalism theory in order to give the States a legitimacy to be comply with international law although the constitution lacks the explicit provisions. The theory contains 2 basic theories which are transnational legal process theory that stresses on how states treat international law properly; and international constitution theory that focuses on how the treatment becomes constitutional.
\end{abstract}

Keywords: Internationalism; Constitution; International Law. 


\section{PENDAHULUAN}

Konstitusi suatu negara lazimnya menjelaskan kedudukan hukum internasional dalam sistem hukum nasional sebagai kesadaran bahwa suatu negara merupakan bagian yang tidak terlepas dari komunitas internasional. Norma pada konstitusi tersebut adalah dasar legitimasi bagi lembaga negara, spesifiknya lembaga peradilan, untuk memanfaatkan hukum internasional dalam sistem hukum nasional secara sah.

Seperti contoh, Article 39 (1) South Africa Constitution memberi preskripsi pada pengadilan untuk menggunakan hukum internasional dalam menginterpretasi nilai-nilai hak asasi manusia. Praktiknya dapat dilihat pada kasus National Commissioner of the South African Police Service vs. Southern African Human Rights Litigation and Another, ${ }^{1}$ ketika Constitutional Court of South Africa merujuk pada treaty yaitu The Rome Statute, kasus internasional seperti Lotus Case, prinsip hukum internasional seperti principle of territoriality dan sumber hukum internasional lain untuk menilai isu konstitusionalitas Keputusan the National Commissioner of South African Police Service yang isinya menolak investigasi terhadap komplain yang diajukan Southern African Human Rights Litigation Centre.

Pemanfaatan hukum internasional yang memiliki otorisasi langsung dari konstitusi menghasilkan keseragaman cara pandang lembaga negara terhadap posisi hukum internasional dalam sistem hukum nasionalnya serta menciptakan konsistensi kepatuhan negara terhadap hukum internasional. Dalam pertemuan ke-27 International Law Commission's Annual Report, Natalie Pierce menyatakan bahwa konstitusi di suatu negara berperan penting untuk melegitimasi the provisional application of treaties supaya tidak terjadi inkonsistensi pelaksanaan kewajiban internasional dan hukum domestik dalam praktiknya. ${ }^{2}$

Indonesia merupakan salah satu contoh negara di mana konstitusinya tidak memuat ketentuan eksplisit yang menjelaskan kedudukan hukum internasional dalam sistem hukum nasional. Undang-Undang Dasar Negara Republik Indonesia Tahun 1945 sebagai konstitusi Indonesia yang telah mengalami 3 fase rezim hukum berbeda ${ }^{3}$ pun tidak menyinggung esensi dari kedudukan hukum internasional dan hanya mengatur kewenangan presiden dan hubungannya dengan dewan

National Commissioner of the South African Police Service vs. Southern African Human Rights Litigation Centre and Another, Case CCT 02/14, Constitutional Court of South African, 30 Oktober 2014.

2 General Assembly, 'As Consideration of International Law Commission Report Concludes, Legal Committee Debates Constitutional Challenges Arising From Treaties' Provisional Application' (2014) <http://www.un.org/press/en/2014/gal3492.doc.htm> diakses 18 Jnui 2015.

3 Tiga rezim berbeda yaitu UUD NRI 1945, Konstitusi RIS 1949, UUD 1950. Damos Dumoli Agusman, 'Dasar Konstitusional Perjanjian Internasional Mengais Latar Belakang dan Dinamika Pasal 11 UUD 1945’ (2012) 4 Opinio Juris 1, 1. 
perwakilan rakyat terkait perjanjian internasional. ${ }^{4}$

Ketiadaan ketentuan eksplisit dalam konstitusi suatu negara seringkali menciptakan ruang perdebatan antar kalangan akademis dalam memandang hukum internasional dalam sistem hukum nasional serta menyebabkan inkonsistensi praktik lembaga negara dalam menggunakan hukum internasional. Mengambil contoh Indonesia, UUD NRI Tahun 1945 tidak menjelaskan posisi hukum internasional sehingga muncul keberagaman pandangan. Di satu sisi, terdapat pandangan bahwa Indonesia tidak dapat menggunakan hukum internasional secara langsung selama hukum internasional tersebut belum ditransformasi ke dalam hukum nasional. Sebagai contoh, penolakan Mahkamah Agung RI terhadap aplikasi the 1958 New York Convention on Recognition and Enforcement of Foreign Arbitral Awards dikarenakan Konvensi tersebut belum memiliki peraturan pelaksana dalam sistem hukum Indonesia pada saat itu. ${ }^{5}$ Di sisi lain, pandangan berbeda menganggap Indonesia dapat menerapkan hukum internasional secara langsung seperti tindakan Mahkamah Agung RI yang menerapkan prinsip the diplomacy community pada Article 31 the 1961 Vienna Convention on Diplomatic Relations untuk menyelesaikan kasus Kedutaan Arab di Indonesia meski
Konvensi tersebut belum ditransformasi ke dalam hukum nasional. ${ }^{6}$

Perbedaan cara pandang di atas juga merupakan ruang perdebatan konseptual teori monisme-dualisme yang kerap digunakan kalangan akademis untuk menjustifikasi posisi hukum internasional di sistem hukum nasional ketika konstitusi suatu negara tidak dapat menjelaskan isu tersebut. Keberagaman pandangan diikuti inkonsistensi praktik ini memunculkan satu pertanyaan mendasar: "Is international law legal or abusive to national law?"

Artikel ini menjawab pertanyaan di atas bahwa international law is legal to national law. Ketiadaan ketentuan eksplisit pada konstitusi suatu negara bukan merupakan alasan fundamental untuk penolakan penggunaan hukum internasional secara langsung di lembaga negara. Teori internasionalisme yang diulas dalam artikel ini merupakan usulan instrumen legitimasi yang konstitusional bagi Indonesia untuk dapat menggunakan hukum internasional secara langsung dalam sistem hukum nasional.

\section{PEMBAHASAN}

\section{Teori Monisme-Dualisme}

Justifikasi terhadap dasar keterikatan negara terhadap hukum internasional umumnya didasarkan pada teori klasik yakni teori monisme

Pasal 11 UUD NRI Tahun 1945.

Sudargo Gautama, Indonesia dan Arbitrase Internasional (Alumni 1992) 17-18.

Simon Butt, 'The Position of International Law Within The Indonesian Legal System' (2014) 28 Emory International Law Review 1, 7. 
dan teori dualisme. Kedua teori tradisional tersebut bertahan sekian lama dengan dasar argumen 'which primacy is used'.

Teori monisme berangkat dari pemikiran bahwa hukum internasional adalah konsekwensi dari basic norm seluruh hukum ${ }^{7}$ dan menitikberatkan hukum internasional dan hukum nasional sebagai satu kesatuan dalam sistem hukum yang terintegrasi ${ }^{8}$. Oleh karenanya, tidak diperlukan suatu proses transformasi hukum internasional ke dalam hukum nasional. ${ }^{9}$ Konsekwensi lebih lanjut, hukum internasional bersifat selfexecuting yakni dapat diterapkan secara langsung. ${ }^{10}$

Berbeda dengan teori monisme, teori dualisme meletakkan primat pada hukum nasional sehingga hukum internasional tidak dapat memaksa negara patuh terhadapnya. ${ }^{11}$ Dengan demikian, teori transformasi dibutuhkan untuk mengubah hukum internasional ke hukum nasional supaya dapat diberlakukan dalam yurisdiksi nasional. ${ }^{12}$ Hasil pemikiran tersebut memberi status hukum internasional sebagai produk hukum yang bersifat non-self-executing.
Namun sayangnya, teori klasik monisme-dualisme kini dinilai kurang memadai dalam memberikan legitimasi penggunaan hukum internasional dalam sistem hukum nasional. Hal tersebut disebabkan oleh beberapa hal:

1. Teori monisme-dualisme bersifat expost yang hanya melihat pada praktik-praktik negara saja.

2. Teori monisme-dualisme kurang mengandung normative content yang tidak dapat digunakan sebagai argumen di pengadilan.

3. Teori monisme-dualisme tidak mampu menghadapi praktik overlapping terhadap teori itu sendiri di suatu negara.

Adanya kelemahan teori tradisional yang disebutkan di atas, maka diperlukan dasar legitimasi lain yang mampu mengakomodir penggunaan hukum internasional secara langsung meski konstitusi tidak mencantumkan ketentuan eksplisitnya.

\section{Teori Internasionalisme}

Teori internasionalisme merupakan usulan solusi atas ketidakmemadainya teori monisme-dualisme dalam memberikan legitimasi penggunaan hukum internasional dalam sistem

Martin Dixon, Textbook on International Law (Blackstone Press Limited 1993) 69.

Hersch Lauterpacht, International Law: Collected Papers (Cambridge University Press 1970) 216. Proses tersebut sering disebut dengan istilah teori incorporation.

10 Damos Dumoli Agusman, Treaties Under Indonesian Law: A Comparative Study (Remaja Rosdakarya 2014) 85.

11 Anthony D'Amato, 'The Coerciveness of International Law' (2010) 91 Faculty Working Papers

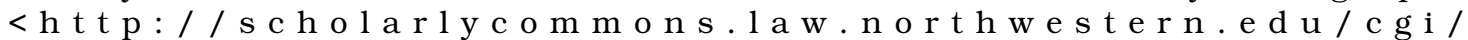
viewcontent.cgi?article $=1090 \&$ context=facultyworkingpapers $>$ diakses 18 Juni 2015.

12 Bahakal Yimer dkk., 'Application of International Investment Agreement by Domestic Courts' (Trade Law Clinic, Geneva, Juni 2011). 
hukum nasional di suatu negara yang tidak memiliki preskripsi eksplisit dalam konstitusinya. Teori internasionalisme dibangun dengan 2 fondasi utama yakni teori transnational legal process dan teori international constitution.

Teori pertama transnational legal process bekerja pada 3 tahap proses utama yaitu interaksi, interpretasi, dan internalisasi norma. ${ }^{13}$ Namun sebelum tahap-tahap tersebut dijelaskan, perlu dipahami terlebih dahulu alasan mengapa negara patuh terhadap hukum internasional.

Pada Mei 2012, Mahamed Jama berkebangsaan Somalia tiba di Malta dan teregistrasi oleh imigrasi Malta sebagai imigran legal. ${ }^{14}$ Ia kemudian ditempatkan di Detention Center kemudian mengajukan perkara ke European Court of Human Rights. Dalam putusannya, ECHR memutus pemerintah Malta telah melakukan pelanggaran terhadap beberapa Article pada European Conventioan Act dan pemerintah wajib membayar kerugian materiil yang diderita Mahamed Jama.

Kasus di atas menggambarkan bagaimana hukum international masuk ke area nasional oleh karena negara patuh terhadap hukum internasional. Lebih lanjut, Harold Koh menjelaskan alasan kepatuhan negara terhadap hukum internasional didasarkan pada keinginan merekonstruksi kepentingan nasional dan identitas negara. ${ }^{15}$ Artinya, sepanjang hukum internasional dapat memenuhi kepentingan nasional suatu negara, maka negara akan membuka dirinya terhadap penerimaan hukum internasional. Juga, kepatuhan negara terhadap hukum internasional akan memberikan predikat yang menguntungkan bagi negara dalam hubungannya dengan negara-negara lain. ${ }^{16}$

Kepatuhan negara terhadap hukum internasional mengantarkan negara ke tahap selanjutnya yakni bagaimana negara tersebut dapat menggunakan hukum internasional di wilayah nasional. Teori transnational legal process mempreskripsi negara untuk melalui 3 tahap mendasar yaitu interaksi, interpretasi, dan internalisasi norma. ${ }^{17}$ Tahap interaksi menjelaskan bagaimana para aktor transnasional berinteraksi dalam suatu forum bersinggungan dengan hukum internasional. Sebagai contoh, pada tahun 1991 pengungsi (refugees) berasal dari Haiti mulai memasuki wilayah Amerika Serikat untuk mencari perlindungan. Meski Amerika Serikat telah meratifikasi the Refugee Convention of 1951 yang di dalamnya

13 Harold Koh, 'International Law as Part Of Our Law' (2004) 98 American Journal of International Law 43, 55.

14 Mahamed Jama vs. Malta, Application No. 10290/13, European Court of Human Rights.

15 Harold Koh, 'Why Do Nations Obey International Law?' (1997) 106 The Yale Law Journal 2599, 2659.

16 Lihat juga teori Andrew Guzman “ Three Rs of Compliance” yang mengungkapkan bahwa kepatuhan terhadap hukum internasional lebih menguntungkan ketimbang ketidakpatuhan. Katherine Tsai, 'How To Create International Law: The Case of Internet Freedom in China' (2011) 21 Duke Journal of Comparative and International Law 401, 410-411. 
terdapat prinsip non-refoulement, namun negara tersebut melakukan pemulangan paksa atas dasar Konvensi a quo tidak melarang pemulangan extraterritorial. Tahap interaksi pun dimulai ketika Harold Koh bersama organisasi internasional lain melakukan gerakan untuk memprotes kebijakan pemulangan tersebut. ${ }^{18}$

Tahap interpretasi adalah aktivitas mengartikan, mengelaborasi, dan menguji definisi dari norma-norma tertentu dalam hukum internasional. ${ }^{19}$ Tujuan dari interpretasi norma untuk memastikan apakah suatu norma yang dirujuk dapat diterapkan (applicable) dalam situasi tertentu secara tepat.

Tahap yang terakhir adalah tahap internalisasi norma. Contoh kasus sama yakni pengungsi Haiti, Harold Koh dan kawan menggunakan "judicialization strategy" untuk memperkuat konsep legal internalization dari norma internasional melawan pemulangan extraterritorial. Artinya, ada penerapan hukum internasional secara langsung pada isu-isu yang berlangsung di wilayah nasional.

Dari serangkaian tahap di atas, nampak bahwa teori transnational legal process berfokus pada vertical domestication dimana norma hukum internasional ditarik ke dalam sistem hukum nasional. ${ }^{20}$ Vertical domestication menempatkan hukum internasional dan hukum nasional pada level yang sama untuk digunakan bersama-sama dalam suatu kasus, atau dengan kata lain disimpulkan "international law as part of our law". ${ }^{21}$

Kebutuhan untuk merujuk pada hukum internasional dapat membantu negara menyelesaikan masalah yang mana solusinya belum didapat oleh karena keterbatasan negara itu sendiri. Apabila hukum internasional dan hukum nasional dapat berjalan bersama dalam lingkup nasional, akan tercipta keseragaman pemahaman terhadap norma-norma tertentu secara universal. Tentunya hal tersebut akan memperkuat standar global terutama di bidang hak asasi manusia (the universal assent of mankind).

Teori kedua dalam teori internasionalisme adalah teori international constitution. Telah diulas sebelumnya mengenai bagaimana negara memperlakukan hukum internasional supaya dapat berlaku dalam sistem hukum nasional. Hal selanjutnya yang perlu diulas adalah bagaimana cara agar penggunaan hukum internasional tidak terjadi secara inkonstitusional. Konstitusi memegang peranan penting dalam memberikan legitimasi penggunaan hukum internasional dalam ruang lingkup

\footnotetext{
17 Harold Koh, 'International Law as Part Of Our Law', Loc.Cit.

18 Harold Koh, 'How Is International Human Rights Law Enforced?' (1999) 74 Indiana Journal Law 1397, 1415-1416.

19 Ibid. 1410.

20 Harold Koh, ‘1998 Frankel Lecture: Bringing International Law Home' (1998) 35 Houston Law Review 623, 626.

21 Frase yang digunakan Justice Gray dalam the Paquete Habana Case (1900).
} 
nasional. Ketentuan eksplisit dalam konstitusi yang menjelaskan posisi hukum internasional menjadi short cut yang jelas untuk mengaplikasi hukum internasional secara konstitusional seperti yang ada pada Konstitusi Afrika Selatan.

Masalah muncul ketika negara yang tidak memiliki ketentuan eksplisit dalam konstitusinya, seperti Indonesia, ingin menggunakan hukum internasional dalam wilayah domestiknya. Pertanyaan mendasarnya apakah lack of the explicit norms menutup kemungkinan suatu negara memanfaatkan hukum internasional? Teori international constitution membantu menyediakan sumber legitimasi bagi negara untuk mengaplikasi hukum internasional meski konstitusi tidak memiliki ketentuan eksplisit dalam batang tubuhnya.

Tiga opsi sumber legitimasi yang ditawarkan teori international constitution $^{22}$ adalah pertama, melihat pada konstitusi masing-masing negara. Aplikasi hukum internasional tidak akan menjadi masalah apabila konstitusi telah menjabarkan secara jelas kedudukan hukum internasional. Kedua, melihat pada keinginan implisit dari konstitusi. Hal ini menjembatani inkapabilitas negara karena keterbatasan tekstual dalam konstitusi. Ketiga, melihat pada tujuan penguatan hak-hak individual.
Artikel ini memberi stressing point pada opsi kedua terkait keinginan implisit dari konstitusi. Konstitusi terkadang mengalami keterbatasan bahasa dalam menjelaskan sesuatu karena konstitusi bersifat sangat general. Oleh sebab itu, diperlukan kemampuan untuk melihat konstitusi beyond the text itself untuk menemukan maksud implisit dari konstitusi. Hal tersebut dapat ditempuh dengan pendekatan sejarah untuk melihat keinginan tersembunyi ketika sebuah konstitusi disusun.

Sebagai contoh, UUD NRI 1945 nyatanya memiliki keinginan implisit untuk berlaku sesuai atau patuh terhadap hukum internasional yang terdapat Pidato Pancasila Soekarno, Naskah Persiapan Undang-Undang Dasar 1945, Pembukaan UUD NRI 1945, dan dokumen sejarah yang lain. Keinginan implisit dalam konstitusi dapat membuka kesempatan bagi negara untuk memanfaatkan hukum internasional dalam sistem hukum nasionalnya secara konstitusional.

Untuk menjamin penggunaan hukum internasional tidak menjadi abusive terhadap sistem hukum nasional, teori international constitution memberi bekal pada para aktor dalam hukum nasional untuk melihat pada penerimaan sistem konstitusional negaranya, menimbang seberapa baik suatu norma internasional terjabarkan 22 Sarah H. Cleveland, 'Our International Constitution' (2006) 31 The Yale Journal of International
Law 1, 7. 
dan diterima secara universal, dan melihat pada kriteria pembatasanpembatasan dalam hukum internasional itu sendiri. ${ }^{23}$ Dalam forum pengadilan, maka hakim memiliki peran penting untuk melakukan filtering di atas supaya tidak terjadi konflik antara hukum internasional dan hukum nasional.

Setiap negara memiliki penerimaan sistem konstitusional terhadap hukum internasional yang berbeda-beda. Kasus the Paquete Habana ${ }^{24}$ mencerminkan Amerika Serikat membuka dirinya terhadap hukum kebiasaan internasional namun bersikap sangat selektif pada international treaties melalui kasus Foster vs. Neilson ${ }^{25}$. Karakteristik penerimaan sistem konstitusional yang demikian harus dipahami seorang hakim di Amerika Serikat dalam mengaplikasi suatu norma hukum internasional dalam sistem hukum nasional negaranya.

Baik teori transnational legal process maupun teori international constitution memiliki fungsi untuk mempermudah jalan negara yang ingin memanfaatkan hukum internasional namun terkendala ketiadaan norma eksplisit pada konstitusi. Teori yang kemudian dikemas dengan nama teori internasionalisme ini menghendaki penggunaan hukum internasional secara proporsional, artinya tidak mengaplikasi hukum internasional secara mentah namun mengkritisi terlebih dahulu kesesuaian antara hukum internasional dan hukum nasional. Dengan demikian, teori internasionalisme dapat mewujudkan pemanfaatan hukum internasional yang konstitusional dalam sistem hukum nasional suatu negara.

\section{PENUTUP}

Artikel ini memberi kesimpulan bahwa ketiadaan norma eksplisit pada konstitusi yang menjelaskan kedudukan hukum internasional dalam sistem hukum nasional tidak serta merta menghilangkan kemampuan suatu negara untuk memanfaatkan hukum internasional dalam ruang domestik. Dasar legitimasi yang didapat tidak didasarkan pada argumen berbasis teori klasik monisme-dualisme, namun dengan argumen berbasis teori internasionalisme.

Pada tataran eksternal, teori transnational legal process memberi legitimasi terhadap penggunaan hukum internasional melalui 3 tahap proses. Sedangkan pada tataran internal, teori international constitution memberi legitimasi dengan melihat konstitusi suatu negara secara kontekstual, bukan tekstual. Pada akhirnya teori internasionalisme menjadi solusi yang lebih memadai bagi negara seperti Indonesia yang memiliki keterbatasan dalam konstitusi untuk menggunakan hukum internasional secara proporsional.

\footnotetext{
23 Sarah H. Cleveland, Op.Cit., 107.

24 The Paquete Habana, 175 U.S. 677, U.S. Supreme Court, 8 Januari 1900.

25 Foster \& Elam vs. Neilson, 27 U.S. 2 Pet. 253, US Supreme Court, 1829.
} 


\section{DAFTAR BACAAN}

Agusman, Damos Dumoli, Treaties Under Indonesian Law: A Comparative Study (Remaja Rosdakarya 2014).

Dixon, Martin, Textbook on International Law (Blackstone Press Limited 1993).

Gautama, Sudargo, Indonesia dan Arbitrase Internasional (Alumni 1992).

Lauterpacht, Hersch, International Law: Collected Papers (Cambridge University Press 1970).

\section{Jurnal}

Agusman, Dumoli, 'Dasar Konstitusional Perjanjian Internasional Mengais Latar Belakang dan DinamikaPasal 11 UUD 1945' (2012) 4 Opinio Juris 1.

Butt, Simon, 'The Position of International Law Within The Indonesian Legal System' (2014) 28 Emory International Law Review 1.

Cleveland, Sarah H., 'Our International Constitution' (2006) 31 The Yale Journal of International Law 1.

Koh, Harold, '1998 Frankel Lecture: Bringing International Law Home' (1998) 35 Houston Law Review 623.

Koh, Harold, 'How Is International Human Rights Law Enforced?' (1999) 74 Indiana Journal Law 1397.
Koh, Harold, 'International Law as Part Of Our Law' (2004) 98 American Journal of International Law 43.

Koh, Harold, 'Why Do Nations Obey International Law?' (1997) 106 The Yale Law Journal 2599.

Tsai, Katherine, 'How To Create International Law: The Case of Internet Freedom in China' (2011) 21 Duke Journal of Comparative and International Law 401.

\section{Internet}

D'Amato, Anthony, 'The Coerciveness of International Law' (2010) 91 Faculty Working Papers <http:// scholarlycommons.law.northwestern.edu/ cgi / viewcontent.cgi ?article $=1090$ \&context=facultyworkingpapers $>$ diakses 18 Juni 2015.

General Assembly, 'As Consideration of International Law Commission Report Concludes, Legal Committee Debates Constitutional Challenges Arising From Treaties' Provisional Application' (2014) <http:// www.un.org/press/en / 2014 / gal3492.doc.htm> diakses 18 Juni 2015.

\section{Seminar}

Yimer, Bahakal dkk., 'Application of International Investment Agreement by Domestic Courts' (Trade Law Clinic, Geneva, Juni 2011). 
